\title{
The Sulphito Complexes of Gold
}

\author{
THEIR CHEMISTRY AND APPLICATIONS IN GOLD \\ ELECTRODEPOSITION
}

\author{
Paul C. Hydes and Harry Middleton
}

Johnson, Matthey \& Co. Limited, London

\begin{abstract}
A new nitro-sulphito gold electrolyte has advantages over available commercial sulphito electrolytes in terms of stability, simplicity of control and the minimum non-porous deposit thickness. In describing its development, the authors review what is known of gold sulphite complexes and their use in gold plating baths.
\end{abstract}

The chemistry of gold is based mainly on two oxidation states and complexes of both gold(I) $\left(\mathrm{d}^{10}\right)$ and gold(III) $\left(d^{8}\right)$ are known. Complexes of gold(I) are generally linear and 2-coordinate but a few tetrahedral 4-coordinate complexes have been characterized. Gold(III) forms 4-coordinate square planar complexes and in thermodynamic terms, -both gold(I) and gold(III) centres form more stable complexes with less electronegative (heavier) donor atoms. This is termed soft or class $b$ behaviour and stability generally decreases with donor atom as follows:

$$
\mathrm{P}>\mathrm{N} \quad \mathrm{S}>\mathrm{O} \quad \mathrm{I}^{-}>\mathrm{Br}^{-}>\mathrm{Cl}^{-}
$$

Sulphite ligands can coordinate to metals through either oxygen or sulphur, thus:

$$
\mathrm{O} \perp \mathrm{S}-\mathrm{M} \text { or } \mathrm{M}-\mathrm{O}-\mathrm{s}_{\mathrm{O}}^{\mathrm{O}}
$$

However, the above predicts that S-bonding will greatly predominate and therefore in the presence of excess sulphite, two major species would be expected, namely $\left[\mathrm{Au}^{(\mathrm{III})}\left(\mathrm{SO}_{3}\right)_{4}\right]^{5-}$ and $\left[\mathrm{Au}^{(I)}\left(\mathrm{SO}_{3}\right)_{2}\right]^{3-}$ :

$$
\left[\begin{array}{cc}
\mathrm{O}_{3} \mathrm{~S} & \mathrm{SO}_{3} \\
\mathrm{O}_{3} \mathrm{~S}^{\mathrm{Au}^{(\mathrm{III})}} & \mathrm{SO}_{3}
\end{array}\right]^{5-}\left[\mathrm{O}_{3} \mathrm{~S}-\mathrm{Au}^{(\mathrm{I})}-\mathrm{SO}_{3}\right]^{3-}
$$

\section{Preparation}

Gold sulphite complexes were first prepared in the 1840 's from the reaction between aqueous sodium sulphite solution and either gold(III) chloride $(1,2)$ or 'fulminating gold' (3) which is the easily detonated precipitate formed on addition of ammonia to gold chloride solution. Colourless or yellow solutions were reported by several authors during this period but in only one case was a solid product isolated and no analytical data were presented (4). Haase was also unsuccessful in characterizing various gold sulphite species (5) and it was only in 1850 that Fremy isolated the gold(III) complex, $\mathrm{K}_{5}\left[\mathrm{Au}\left(\mathrm{SO}_{3}\right)_{4}\right] .5 \mathrm{H}_{2} \mathrm{O}$, and the corresponding sodium salt by the reaction of sodium aurate (see below) with potassium bisulphite (6). The yellow complexes are stable in air for several hours, but neutral or acidic solutions rapidly decompose to metallic gold with the evolution of sulphur dioxide. Alkaline solutions are stable and become colourless on heating, probably due to formation of gold(I) species (7). Several workers attempted to isolate $\left[\mathrm{Au}\left(\mathrm{SO}_{3}\right)_{4}\right]^{5-}$ and $\left[\mathrm{Au}\left(\mathrm{SO}_{3}\right)_{2}\right]^{3-}$ complexes from such solutions by concentration and precipitation with alcohol $(7,8)$ but the products generally gave irreproducible analyses due to both incomplete reduction and the coprecipitation of excess sodium or potassium salts. However, alcohol precipitation of solutions prepared by the reaction of sodium aurate and sodium sulphite yielded a yellow complex displaying a red-green fluorescence; this was subsequently characterized as $\mathrm{Na}_{5}\left[\mathrm{Au}\left(\mathrm{SO}_{3}\right)_{4}\right] .5 \mathrm{H}_{2} \mathrm{O}$.

Despite the considerable amount of literature on gold sulphite complexes there are no reports of preparations using gold hydroxide, or sulphur dioxide as the sulphiting agent. The addition of sulphur dioxide gas to sodium aurate solution, prepared by reaction of excess sodium hydroxide with $\left[\mathrm{AuCl}_{4}\right]^{-}$ solution, results in precipitation of a yellow solid, the infra-red spectrum of which is similar to that of samples of the gold(III) complex $\left[\mathrm{Au}\left(\mathrm{SO}_{3}\right)_{4}\right]^{5-}$ prepared by alternative routes. This product can be washed and dried with ethanol and ether but addition of water results in violent decomposition. Addition of gold hydroxide to sodium bisulphite solution gives rapid decomposition to gold. Using sodium sulphite, a yellow precipitate of $\left[\mathrm{Au}\left(\mathrm{SO}_{3}\right)_{4}\right]^{5-}$ is formed which 
Table 1

Vibrational Frequencies for Sulphito Complexes

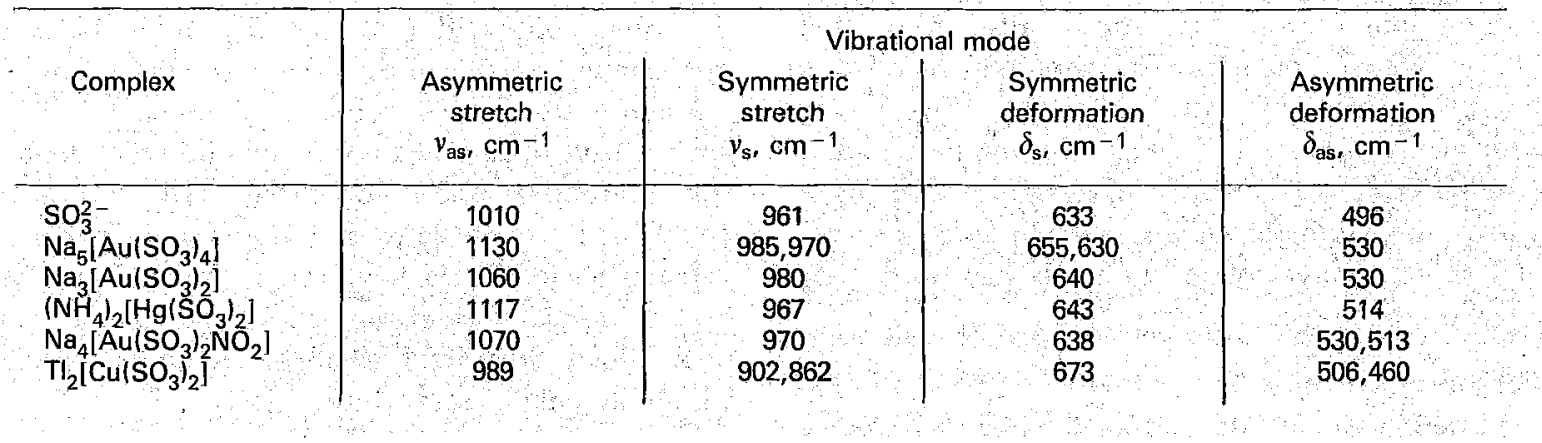

dissolves on heating to form a colourless solution of $\left[\mathrm{Au}\left(\mathrm{SO}_{3}\right)_{2}\right]^{3-}$ as a result of reduction by alkaline sulphite (9). Thus:

$$
\mathrm{Au}(\mathrm{III})+\mathrm{SO}_{3}^{2-}+2 \mathrm{OH}-\mathrm{Au}(\mathrm{I})+\mathrm{SO}_{4}^{2-}+\mathrm{H}_{2} \mathrm{O}
$$

Concentration of the above solution results in precipitation of a yellow-pink air stable product, $\mathrm{Na}_{3}\left[\mathrm{Au}\left(\mathrm{SO}_{3}\right)_{2}\right]$, with an infra-red spectrum characteristic for S-bonded sulphito complexes (see Table I).

There are four vibrational modes for the pyramidal sulphite ion which has $\mathrm{C}_{3 v}$ symmetry (Table I). If the sulphite is S-bonded and monodentate, the $\mathrm{C}_{3 \mathrm{v}}$ symmetry of the ligand is unchanged and $v_{s}$ and $v_{\text {as }}$ will have higher frequencies than in the free ion. If the sulphite is O-bonded, however, the symmetry of the group is lowered to $\mathrm{C}_{s}$. Consequently the ligand should show three stretching absorptions, due to the loss of degeneracy for $v_{a s}$ and one of these frequencies should be lower than in the free ion. $\delta_{\text {as }}$ would also be split if the sulphite was $\mathrm{O}$-bonded, although degenerate modes can be split without loss of molecular symmetry in some crystalline complexes due to a lowered site (or lattice) symmetry. The infrared spectrum for the gold(III) sulphite is complicated due to the multiplicity of ligands but is at a higher frequency $\left(1130 \mathrm{~cm}^{-1}\right)$ than in the gold(I) sulphite $\left(1060 \mathrm{~cm}^{-1}\right)$. The spectrum of $\mathrm{Na}_{3}\left[\mathrm{Au}\left(\mathrm{SO}_{3}\right)_{2}\right]$ fits the general criteria of S-bonded sulphites as can be seen in Table I, where data for the S-bonded sulphito complex ammonium bis(sulphito)mercury(II) which is isoelectronic with $\left[\mathrm{Au}\left(\mathrm{SO}_{3}\right)_{2}\right]^{3-}$ and for the O-bonded sulphito complex $\mathrm{Tl}_{2}\left[\mathrm{Cu}\left(\mathrm{SO}_{3}\right)_{2}\right]$ are included for comparison (10).

Potentiometric titrations of aqueous sodium sulphite with fulminating gold at a range of buffered $\mathrm{pH}$ values indicate that the reduction (1) above is rapid as determined by an inflection in the potential curve after addition of 1 molar equivalent of sulphite. Further addition of sulphite solution results in sulphite complexation where the inflection of the potential plot occurs at a sulphite-gold mole ratio of 3:1 and suggests the formulation $\left[\mathrm{Au}\left(\mathrm{SO}_{3}\right)_{2}\right]^{3-}$ for the gold species in solution. However, when the above titration is carried out in the absence of a buffer, a distinct change in potential is observed at a 1:1 mole ratio as before, but further addition of sulphite only results in a colour change for the slurry, without dissolution, and indicates the presence of an insoluble gold(I) species (9).

It has been suggested that gold(III) sulphite species are more stable than the analogous gold(I) complexes based on comparisons of the standard reduction potentials for the respective gold and silver complexes. The authors (11) concluded that reduction of $\left[\mathrm{AuCl}_{4}\right]^{-}$by sulphur dioxide proceeds via a colourless gold(III) sulphite complex and solutions prepared by this method gave an ultra-violet spectrum containing only peaks 'characteristic of $\mathrm{Au}$ (III) species'. It is possible that a mixed chloro-sulphite complex is formed and that these observations reflect the $\mathrm{pH}$ dependence of the reaction. Addition of sulphur dioxide to yellow sodium aurate solutions $(\mathrm{pH}$ 13) results in precipitation of the yellow $\left[\mathrm{Au}\left(\mathrm{SO}_{3}\right)_{4}\right]^{3-}$ complex at $\mathrm{pH}$ 9, which redissolves as the colourless gold(I) complex $\left[\mathrm{Au}\left(\mathrm{SO}_{3}\right)_{2}\right]^{-}$. This solution is stable down to $\mathrm{pH} 3$ and the complex can be isolated and is stable on prolonged storage in air. However, addition of sulphur dioxide to intermediate $\left[\mathrm{AuCl}_{\mathrm{x}}(\mathrm{OH})_{4 \cdot \mathrm{x}}\right]^{-}$species formed during reaction of excess sodium hydroxide with $\left[\mathrm{AuCl}_{4}\right]^{-}$results in reduction to gold without precipitation of any sulphito-gold species.

Ammine sulphito complexes of gold were originally prepared by reaction of gold chloride with ammonium sulphite solution but although white crystalline products were isolated, the elemental analysis did not conform to a stoichiometric formulation (8). A gold(III) complex was isolated (12) by reaction of ethylenediamine with $\left[\mathrm{AuCl}_{4}\right]^{-}$solution followed by addition of sodium sulphite to form the square planar yellow complex $\mathrm{Na}\left[\mathrm{Au}\left(\mathrm{SO}_{3}\right)_{2}(\mathrm{en})\right]$, the structure of which has been determined (13). The 
formation of gold(I) ammine sulphito species has been reported (9) during the reaction of ammonia with sodium gold sulphite prepared by Elsners' method (3), in which potentiometric titrations revealed a potential inflection after addition of 2 molar equivalents of ammonia, suggesting the formulation $\left[\mathrm{Au}\left(\mathrm{SO}_{3}\right)_{2}\left(\mathrm{NH}_{3}\right)_{2}\right]^{3-}$. Similar observations were made when using aliphatic amines, and additions in excess of 2 molar equivalents of ammonia had no further effect on the potential curves.

\section{Electrochemistry}

There are no reliable data on stability or standard reduction potentials for gold sulphite complexes, and a range of values for the latter is to be found in the literature $(14,15)$ :

$$
\mathrm{Au} /\left[\mathrm{Au}\left(\mathrm{SO}_{3}\right)_{2}\right]^{3-} \quad \mathrm{E}^{\circ}=0.06 \text { to } 1.02 \mathrm{~V}
$$

Cyclic voltammetry and polarization curve determinations have been used (16) to study the mechanism of gold electrodeposition from $\left[\mathrm{Au}\left(\mathrm{SO}_{3}\right)_{2}\right]^{3-}$ solution, with the conclusion that two distinct processes operate depending on the $\mathrm{pH}$. In neutral solution, chemical reduction by dithionite ion probably occurs as follows:

$$
\begin{aligned}
& \mathrm{SO}_{3}^{2-}+\mathrm{H}_{3} \mathrm{O}^{+} \leftrightharpoons \mathrm{HSO}_{3}^{-}+\mathrm{H}_{2} \mathrm{O} \\
& 2 \mathrm{HSO}_{3}^{-}+2 \mathrm{e}^{-} \leftrightharpoons \mathrm{S}_{2} \mathrm{O}_{4}^{2-}+2 \mathrm{OH}^{-} \\
& 2\left[\mathrm{Au}\left(\mathrm{SO}_{3}\right)_{2}\right]^{3-}+\mathrm{S}_{2} \mathrm{O}_{4}^{2-}+2 \mathrm{OH}^{-} \leftrightharpoons 2 \mathrm{Au}+2 \mathrm{HSO}_{3}^{-}+4 \mathrm{SO}_{3}^{2-}
\end{aligned}
$$

whereas at high $\mathrm{pH}$, direct reduction of $\left[\mathrm{Au}\left(\mathrm{SO}_{3}\right)_{2}\right]^{3-}$ is observed as follows:

$$
\left[\mathrm{Au}\left(\mathrm{SO}_{3}\right)_{2}\right]^{3-}+\mathrm{e}^{-} \Leftrightarrow \mathrm{Au}+2 \mathrm{SO}_{3}^{2-}
$$

Pulsed potentiostatic kinetic experiments (17) with a similar $\left[\mathrm{Au}\left(\mathrm{SO}_{3}\right)_{2}\right]^{3-}$ electrolyte confirmed that the latter, strongly mass transfer-controlled process, occurs at cathode potentials more negative than $-0.8 \mathrm{~V}$ and an electrolyte $\mathrm{pH}$ above 8.5. However, at less negative potentials a two step process was indicated:

$$
\begin{aligned}
{\left[\mathrm{Au}\left(\mathrm{SO}_{3}\right)_{2}\right]^{3-} } & \leftrightharpoons \mathrm{Au}_{\mathrm{ads}}^{+}+2 \mathrm{SO}_{3}^{2-} \\
\mathrm{Au}_{\mathrm{ads}}^{+}+\mathrm{e}^{-} & \rightarrow \mathrm{Au}
\end{aligned}
$$

where the decreased stability of the complex below pH 8 would support such a dissociative mechanism. The presence of excess sulphite results in a pronounced change in the observed polarization curves due to displacement of the above equilibrium towards $\left[\mathrm{Au}\left(\mathrm{SO}_{3}\right)_{2}\right]^{3-}$ formation. However, this does not prevent decomposition of the complex on standing due to the disproportionation reaction and colloidal gold formation is observed (9) with such solutions:

$$
3 \mathrm{Au}^{+} \leftrightharpoons 2 \mathrm{Au}+\mathrm{Au}^{3+}
$$

The current density is also thought to affect the deposition mechanism and tests on one commercial electrolyte indicated (18) that deposition becomes autocatalytic at current densities above $0.4 \mathrm{~A} / \mathrm{dm}^{2}$.

Electrolysis of gold sulphite solutions to which amines have been added results in a different deposition potential when compared with un-doped $\left[\mathrm{Au}\left(\mathrm{SO}_{3}\right)_{2}\right]^{3-}$ electrolytes and there is no potential dependance on the excess of amine present. This has been attributed to formation of a sulphito amine complex which dissociates to form. an amine species which does not dissociate appreciably:

$$
\begin{aligned}
{\left[\mathrm{Au}\left(\mathrm{SO}_{3}\right)_{2}(\mathrm{~A})_{2}\right] } & \leftrightharpoons\left[\mathrm{Au}(\mathrm{A})_{2}\right]^{+}+2 \mathrm{SO}_{3}^{2-} \\
{\left[\mathrm{Au}(\mathrm{A})_{2}\right]^{+} } & \leftrightharpoons \mathrm{Au}^{+}+2 \mathrm{~A}
\end{aligned}
$$

where $\mathrm{A}=$ amine $\left(\mathrm{RNH}_{2}\right)$.

Colloidal gold formation is not observed during storage of this electrolyte (9) and analogous $\left[\mathrm{Au}(\mathrm{A})_{2}\right]^{+}$ species have recently been isolated (19). The increased stability of the amine complex facilitates electrodeposition at solution $\mathrm{pH}$ 's lower than those attainable with conventional electrolytes. This has resulted in a significant increase in the possible range of codeposited metals in alloy electrolytes, and consequently also the number of applications for deposits from non-cyanide electrolytes.

\section{Electrolyte Development}

Despite the long history of chemical and electrochemical studies on sulphite complexes, commercial exploitation of sulphite electrolytes occurred only after 1962 when Smith patented an electrolyte, prepared by Elsner's method, which also contained trace additions of copper as a brightening agent (20). Although this system had a low operating current density, it was used to prepare $130 \mu \mathrm{m}$ thick, ductile deposits and exhibited excellent throwing power with a cathode efficiency of effectively 100 per cent. Shoushanian (21) subsequently demonstrated that a variety of metal additives could be used in this system to form alloy deposits, provided strong agitation was used to prevent peeling; commercial versions rely primarily on the use of cadmium as an addition. Both series of electrolytes operate at high $\mathrm{pH}$ and are very similar in composition to several baths developed by Baker (22). In 1969, Smagunova et al. (23) developed electrolytes operable at neutral $\mathrm{pH}$ using ethylenediamine, and additions of other organic amines were subsequently investigated in great detail by Losi et al. (24), especially with regard to formation of gold-copper alloys. Using EDTA as an additive, control of the electrolyte proved extremely difficult, but with alkylamines it was found that low carat alloys could be deposited with extensive formation of phases such as $\mathrm{Cu}_{3} \mathrm{Au}$ and $\mathrm{Au}_{3} \mathrm{Cu}$. These deposits 
showed high corrosion resistance in contrast to several 'alloy' systems where segregation of the constituents occurs. A comprehensive review of the range of alloy sulphite electrolytes and their deposit properties has appeared previously in this journal (25) and therefore, further discussion here will be limited to high carat systems.

Simple sulphite electrolytes based upon the $\left[\mathrm{Au}\left(\mathrm{SO}_{3}\right)_{2}\right]^{3-}$ complex are unstable on storage, as discussed above, and are difficult to control during operation due to rapid fluctuations in $\mathrm{pH}$. Accurate temperature control is also required as high cathode efficiencies are only attainable at elevated temperatures $\left(40\right.$ to $\left.60^{\circ} \mathrm{C}\right)$. Electrolyte replenishment is via a concentrated solution which leads to problems of bath volume control. The recovery and disposal of spent electrolytes is not hampered by the presence of highly toxic species such as those in gold cyanide electrolytes, but the liquors still require special treatment due to the high biological oxygen demand of sulphite solutions (26) which is not compatible with municipal effluent processing.

\section{Deposit Properties}

X-ray diffraction studies have shown that deposits from an arsenic-brightened sulphite electrolyte (U.S. Patent 3,474,292) nucleate and grow with predominantly $\{220\}$ or $\{200\}$ orientations at low current densities (18). Increase in the current density leads to random orientation and microscopic examination reveals (27) a uniform fine-grained structure with a mean crystallite size of $0.04 \mu \mathrm{m}$. Cyanide systems, however, nucleate with a $\{111\}$ orientation and as deposition proceeds, higher order orientations, especially $\{311\}$, are promoted unless cobalt brighteners are added to the baths in which case the $\{111\}$ orientation is maintained. As there are differential degrees of lattice packing for different orientations, it is possible that the mechanical properties of deposits will vary according to the preferred orientation (18). This may contribute to the high wear resistance of cobalt-hardened acid cyanide golds in contrast to the rapid 'galling' of deposits from sulphite electrolytes. The latter deposits are highly ductile and have good distribution but the pronounced levelling effects observed with these systems preclude their use for the plating and especially electroforming of substrates with fine relief.

Modern electroplating techniques such as ultrasonic agitation have enabled formation of nonporous gold deposits from cyanide electrolytes at thicknesses of 2 to $3 \mu \mathrm{m}$ compared with $5 \mu \mathrm{m}$ for both sulphite and cyanide systems using traditional techniques. However, no improvement in porosity was noted with a standard sulphite electrolyte when ultrasonic agitation was used, and in fact the latter was detrimental to the colour of the deposit (28). Pulse-plating has also been applied to cyanide electrolytes to improve physical properties, especially to reduce the stresses in the deposit, but due to the irreversibility of the gold/gold(I) couple in sulphite solutions, there is no frequency dependence of deposit properties with them (17). However, the extent of voltage ripple can affect stresses in the deposits from sulphite electrolytes, notably in a gold-cadmium alloy electrolyte (27) where a direct current effectively trebled the internal tensile stress relative to its value when an unsmoothed power source was used.

\section{Applications}

Despite the proliferation in recent years of sulphite electrolytes and of evaluation data on their deposits, the electronics industry, which is the major consumer of gold electroplate, has been extremely reluctant to accept sulphite systems. Pure gold deposits from noncyanide electrolytes have poor wear characteristics exemplified by rapid self-welding under reciprocal wear conditions and their use as coatings on insertion contacts is possible only if mated with a contact prepared from a cyanide system (29). Also, given the requirements for maximum economy of gold utilization in modern plating applications, a sulphite electrolyte is unlikely to find widespread acceptance for the production of electrical contacts, despite the excellent distribution, unless it can be operated in selective plating assemblies. Consequently the major application for sulphite electrolytes is for the production of decorative items.

\section{Nitro-Sulphito Gold(I) Electrolytes}

In an attempt to overcome some of the disadvantages of current commercial gold sulphite systems discussed earlier, Johnson Matthey Research have developed a new electrolyte formulation (30) based on a gold complex isolated from the reaction of sodium nitrite with $\left[\mathrm{Au}\left(\mathrm{SO}_{3}\right)_{2}\right]^{3-}$. Nitrite ion does not react with $\left[\mathrm{Au}\left(\mathrm{SO}_{3}\right)_{4}\right]^{5-}$ under the same conditions. The new nitro complex can be formulated as $\mathrm{Na}_{4}\left[\mathrm{Au}\left(\mathrm{SO}_{3}\right)_{2}\left(\mathrm{NO}_{2}\right)\right] \cdot \mathrm{NaNO}_{2}$ and prolonged washing with water or ethanol removes the excess nitrite to give a complex which analyses as $\mathrm{Na}_{4}\left[\mathrm{Au}\left(\mathrm{SO}_{3}\right)_{2}\left(\mathrm{NO}_{2}\right)\right]$. X-ray powder diffraction gives a pattern consistent with an orthorhombic unit cell with lattice parameters:

$$
a=0.86 \mathrm{~nm}, b=1.038 \mathrm{~nm}, c=1.536 \mathrm{~nm}
$$

The splitting of two of the lines assigned to the complex increases slightly with the free nitrite content, probably due to lattice expansion caused by sodium nitrate within the unit cell. The infra-red spectrum reveals absorptions due to $\dot{S}$-bonded 
Table II

Vibrational Frequencies for Nitro Complexes

\begin{tabular}{|c|c|c|c|}
\hline \multirow[b]{2}{*}{ Complex } & \multicolumn{3}{|c|}{ Vibrational mode } \\
\hline & $\begin{array}{c}\text { Asymmetric } \\
\text { stretch } \\
\gamma_{\mathrm{as}}\left(\mathrm{NO}_{2}\right)_{, \mathrm{cm}}^{-1}\end{array}$ & $\begin{array}{c}\text { Symmetric } \\
\text { stretch } \\
v_{\mathrm{s}}\left(\mathrm{NO}_{2}\right), \mathrm{cm}-1\end{array}$ & $\begin{array}{c}\text { Symmetric } \\
\text { deformation } \\
\delta_{\mathrm{s}}\left(\mathrm{NO}_{2}\right), \mathrm{cm}^{-1}\end{array}$ \\
\hline $\begin{array}{l}\mathrm{NO}_{2} \\
\mathrm{Na}_{4}\left[\mathrm{Au}\left(\mathrm{SO}_{3}\right)_{2}\left(\mathrm{NO}_{2}\right)\right]\end{array}$ & $\begin{array}{l}1325 \\
1343 \\
1468\end{array}$ & $\begin{array}{l}1265 \\
1297 \\
1065\end{array}$ & $\begin{array}{l}829 \\
822 \\
825\end{array}$ \\
\hline
\end{tabular}

the electrolyte is intermediate between those for current commercial cyanide and sulphite systems but levelling effects such as those which characterize the latter have not been observed.

Deposits on copper substrates from vat, barrel and electroforming operations are bright, coherent and adherent. Hardness values lie in the range 120 to 140 VPN and the deposit surfaces

sulphito ligands (Table I) and also both N-bonded nitro and free nitrite groups. Table II compares the observed frequencies for the nitro group with both the free nitrite ion absorptions and also those for the O-bonded nitrito complex $\left[\mathrm{Co}(\mathrm{ONO})\left(\mathrm{NH}_{3}\right)_{5}\right]^{2+}$ as reported by Terzis et al. (31). The complex can be reprecipitated from aqueous solution by addition of excess sodium nitrite and is air stable, but freshly prepared electrolytes are routinely carbon treated as a precaution against traces of colloidal gold which may be formed by decomposition during prolonged storage. The electrolyte consists of an aqueous solution of the complex with buffer, stabilizer and brightener additives and is operated at ambient temperature with high cathode efficiency ( 90 per cent) at $\mathrm{pH} 11$. Replenishment is effected by dissolution of the complex in a sample of the electrolyte followed by addition to the bath which is operated with continuous filtration. The throwing power for

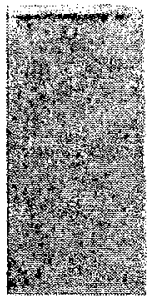

$0.5 \mu \mathrm{m}$

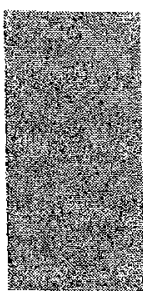

$2.0 \mu \mathrm{m}$

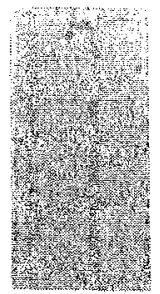

$1.0 \mu \mathrm{m}$

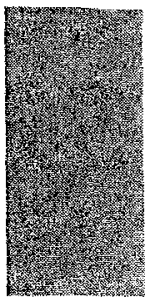

$2.5 \mu \mathrm{m}$

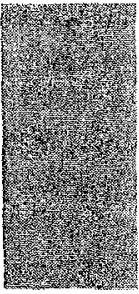

$1.5 \mu \mathrm{m}$

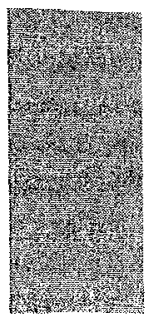

$\mathbf{3 . 0} \mu \mathbf{m}$
Cadmium sulphide electrographic test papers for 0.5 to 3.0 $\mu \mathrm{m}$ thick gold deposits on copper from the Johnson Matthey nitro-sulphito electrolyte. The deposits were free from porosity at a thickness of $2 \mu \mathrm{m}$ have a preferred $\{111\}$ orientation in contrast to other sulphite electrolytes. The incidence of porosity is substantially lower than with other electrolytes operated under standard conditions as deposits $2 \mu \mathrm{m}$ thick are non-porous. At lower thicknesses where porosity does occur, pooling of corrosion products is less extensive than with cobalt-hardened gold cyanide deposits and appears to result from a different mechanism. Electroforming with this type of bath is facilitated by the low stresses in the highly ductile deposits which have been prepared at thicknesses up to $250 \mu \mathrm{m}$ and the absence of levelling effects is such that substrate relief is accurately reproduced.

Contact resistance measurements resulted in mean values of $1.05 \pm 0.05$ and $0.51 \pm 0.05 \mathrm{~m} \Omega$ at contact loadings of 0.1 and $0.25 \mathrm{~N}$ respectively, and the solderability is excellent with a flow-round time of $4.6 \mathrm{~s}$ for a $5 \mu \mathrm{m}$ thick deposit on a copper test wire.

Preliminary work on the effect of alloying additives in the nitro-sulphito electrolytes has shown that trace levels of copper $(0.02 \mathrm{~g} / \mathrm{l})$ improve the maximum operating current density to $0.4 \mathrm{~A} / \mathrm{dm}^{2}$ (10 g/l gold) and $0.8 \mathrm{~A} / \mathrm{dm}^{2}(30 \mathrm{~g} / 1$ gold) without detriment to electrolyte performance or deposit quality. The cathode efficiency with these electrolytes is increased to 98 per cent and the deposit hardness is in the region of 150 to 200 VPN depending on the operating current density and gold concentration. Although stresses in alloyed deposits are slightly higher than those in pure gold deposits, the increments are not deleterious and electroforms up to $600 \mu \mathrm{m}$ in thickness have been prepared with a copper content of 0.1 per cent.

The pure gold electrolytes are primarily used in decorative applications where the formation of $2 \mathrm{~m}$ thick non-porous deposits constitutes a marked advantage over other sulphite and cyanide electrolytes as the latter systems require special operating procedures to obtain similar porosity levels -- and hence corrosion resistance - at this thickness. However, barrel-plated and electroformed deposits have also been used in specialized electronic applications such as slip-rings where exceptionally low electrical noise levels were recorded. 
The new gold electrolyte is suitable for electroforming. The two pieces of tubing shown here were grown externally on a copper former, the ring was cut from a piece of electroformed tube and successfully faceted by machining, while the cameo was developed from the front in a rubber mould

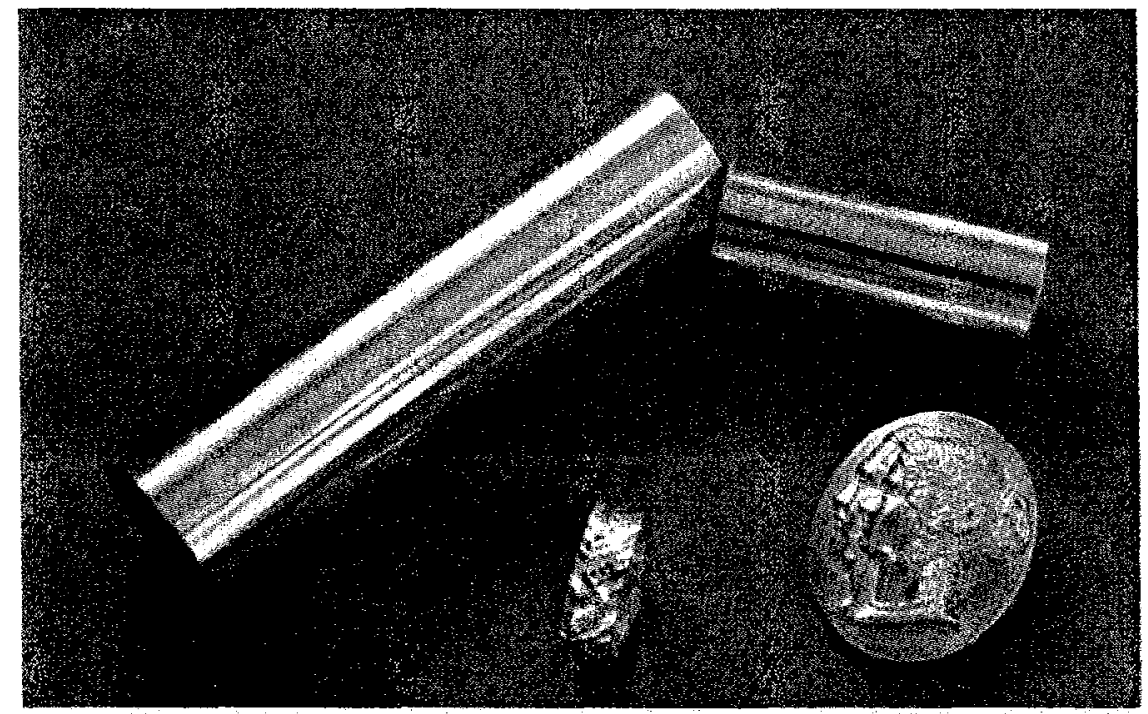

Another example of the usefulness of the nitrosulphito gold electrolyte for electroforming. This small elephant was formed over a wax model by B.J.S. Electro Plating of London. Not only does this process faithfully reproduce the detail of the original but it also makes possible a reduction in wall thickness and so a saving in gold by comparison with casting techniques

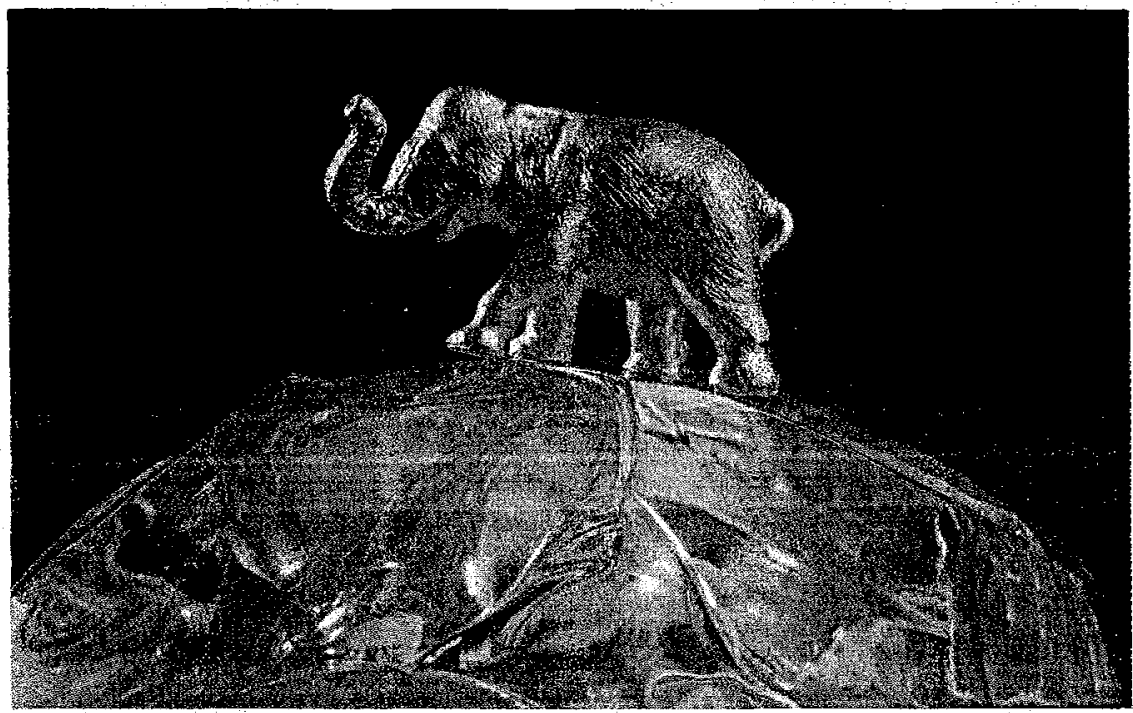

\section{References}

1 J. S. Woolrich, British Patent 9431 (1842)

2 J. S. Woolrich, Dinglers polytech. $7 ., 1843,88,48$

3 F. C. L. Elsner, f. Prakt. Chem., 1845, 35, 361

4 C. Himly, Liebigs Ann., 1846, 59, 95

5 A. Haase, Rostok, 1849, see (7)

6 E. Fremy, Ann. Chim. Phys., 1850, 31, 478

7 B. Oddo and Q. Mingoia, Gaz. Chim. Ital., 1927, 57, 820-826

8 A. Rosenheim, J. Hertzmann and M. Pritz, Z. Anorg. Chem., 1908, 5p, 198

9 J. Socha, S. Safarzynuki and T. Zak, F. Less-Common Met., $1975,43,283-290$

10 G. Newman and D. B. Powell, Spectrochim. Acta, 1963, 19, 213

11 N. P. Finkelstein and R. D. Hancock, Gold Bull., 1974, 7, (3), $72-77$

12 F. Zuntini, G. Aliprandini, J. M. Gioria, A. Meyer and S. Losi, U.S. Patent 3,787,463 (1974)

13 A. Dunand and R. Gerdil, Acta Crystallogr, 1975, B31 370-374

14 V. P. Kazakov and M. V. Konovalova, Zh. Neorg. Khim., $1968,13,447-453$

15 B. I. Perschevitskii and A. M. Erenburg, Izv. Sib. Otd. Akad. Nauk SSSR., 1970, 4, 83-87

16 J.-P. Derivaz, A. Resin and S. Losi, Surf. Technol., 1977, 5, 369-377

17 J. Horkans and L. T. Romankiw, f. Electrochem. Soc., 1977, 124, (10), 1499-1505
18 R. J. Morrisey and A. M. Weisberg, Trans. Inst. Met. Finish. $1975,53,(1), 9-16$

19 N. A. Malik, P. J. Sadler, S. Neidle and G. L. Taylor, Chem Commun., 1978, 711-712

20 P. T. Smith, U.S. Patent 3,057,789 (1962)

21 H. H. Shoushanian, U.S. Patent 3,475,292 (1969)

22 K. D. Baker, U.S. Patent 3,776,822 (1973)

23 N. A. Smagunova, J. P. Gavrilova and N. N. Balashova, Sov. Union Patent 231992 (1968)

24 S. Losi, F. L. Zuntini and A. Meyer, Electrodepos. Surf. Treat, $1972 / 3,1,3-19$

25 W. A. Fairweather, Gold Bull., 1977, 10, (1), 15-20

26 D. G. Foulke in 'Gold Plating Technology', edited by F. H. Reid and W. Goldie, Electrochemical Publications, Ayr Scotland, 1974 , p. 56

27 W. H. Cleghorn, J. A. Crossley, K. H. Lodge and K. S. A. Gnanasekaran, Trans. Inst. Met. Finish., 1972, 50, (2), 73-76

28 C. Barnes and J. J. B. Ward, Trans. Inst. Met. Finish., 1977 55, 101-103

29 J. W. Souter, IEEE Trans. Parts Hybrids Packag., 1974 PHP10, 18

30 C.W. Bradford and H. Middleton, British Patent 1416152 (1975)

31 K. Nakamoto, J. Fujita and H. Murata, f. Am. Chem. Soc., $1958,80,4817$ 